\title{
PRODUKSI DAN PEMASARAN KOMODITAS BROILER DI JAWA BARAT
}

\author{
Saptana $^{* 1}$, Mohamad Maulana*), dan Rahayu Ningsih ${ }^{* *}$ \\ *) Pusat Sosial Ekonomi dan Kebijakan Pertanian \\ Jl. Tentara Pelajar No 3B Komplek Kampus Pertanian, Cimanggu, Bogor 16111 \\ **) Badan Pengkajian dan Pengembangan Perdagangan, Kementerian Perdagangan \\ Jl. M.I. Ridwan Rais No. 5 Jakarta Pusat 10110
}

\begin{abstract}
The development of broiler industry can be a basis for the economic growth and employment opportunities. There are three broiler breeding patterns i.e. independent breeders, internal-business partnerships, and external-business partnerships. This research aims to analyze broiler production and marketing in West Java Province. The research objectives are: (1) to analyze the performance of each broiler breeding farm; (2) to analyze the market structure of broilers; (3) to evaluate the marketing margin of broilers; and (4) to study market integration of broilers. The method used in this study was a survey method using structured questionnaires. The primary and secondary data used in this study were analyzed using the broiler breeding feasibility analysis, $R / C$ ratio, marketing margin, and market integration analysis. The results showed that: (1) broiler breeding business in various patterns remains profitable and has an effective return to capital in moderate level, (2) both independent and plasma broiler breeders face an oligopolistic market structure, and the brokers also confronts oligopolistic market structure in dealing with the core enterprise through specific prices, and (3) retailers receive the biggest profit margin per unit of output, while the inter-regional wholesalers receive the largest total margin due to its large sales turnover, and (4) broiler markets are not integrated. In summary it can be concluded that broiler farming in various business patterns is profitable; however, and the marketing system is inefficient.
\end{abstract}

Keywords: $R / C$ ratio, market structure, marketing margins, market integration, broiler

\begin{abstract}
ABSTRAK
Pengembangan komoditas broiler dapat menjadi basis pertumbuhan ekonomi dan pemerataan kesempatan kerja jika dikelola dengan baik. Paling tidak terdapat tiga pola usaha ternak broiler yakni usaha ternak mandiri, kemitraan usaha internal dan kemitraan usaha eksternal. Tujuan penelitian adalah (1) mmenganalisis kinerja usaha ternak broiler; (2) menganalisis struktur pasar komoditas broiler; (3) menganalisis margin tataniaga komoditas broiler; dan (4) menganalisis integrasi pasar komoditas broiler. Metode yang digunakan dalam penelitian ini adalah metode survei dengan menggunakan kuesioner terstruktur. Data kuantitatif dianalisis menggunakan analisis kelayakan usaha ternak, $R / C$ ratio, marjin tataniaga dan analisis integrasi pasar. Hasil penelitian menunjukkan bahwa: (1) usaha ternak broiler pada berbagai pola usaha masih tetap menguntungkan dan memiliki efektivitas pengembalian modal pada level moderat; (2) peternak baik mandiri maupun peternak plasma menghadapi struktur pasar yang oligopsonistik dan pedagang pengepul/broker menghadapi struktur pasar yang oligopolistik dalam berhadapan dengan perusahaan inti melalui harga Posko; (3) pedagang pengecer menerima rata-rata margin keuntungan terbesar per unit output, sedangkan pedagang besar antar wilayah menerima margin total terbesar karena omzet penjualan yang besar; dan (4) pasar komoditas broiler tidak terintegrasi, secara relatif peternak ke pedagang besar tidak terintegrasi dan pedagang besar ke pedagang pengecer secara relatif lebih terintegrasi. Secara ringkas dapat disimpulkan bahwa usaha ternak broiler pada berbagai pola usaha menguntungkan dan sistem pemasaran yang belum efisien.
\end{abstract}

Kata kunci: $R / C$ ratio, struktur pasar, margin pemasaran, integrasi pasar, broiler

\footnotetext{
${ }^{1}$ Alamat Korespondensi:

Email: saptono_07@yahoo.co.id
} 


\section{PENDAHULUAN}

Industri broiler merupakan basis ekonomi yang berpotensi tinggi dalam meningkatkan pertumbuhan ekonomi dan pemerataan kesempatan kerja secara luas. Industri broiler di Indonesia berkembang mulai tahun 1970-an ketika ayam ras modern dikenalkan oleh perusahaan swasta sehingga pada tahun 2013 Indonesia sudah menghasilkan lebih dari 2 miliar ekor broiler (Ditjen PKH, 2013). Hasil produk broiler memberikan kontribusi kurang lebih $65 \%$ terhadap kebutuhan daging nasional yang pada awal mulanya dipenuhi oleh daging sapi (Ditjen PKH, 2013).

Hasil penelitian Aho (1998) yang juga diacu oleh Tangenjaya (2014) menunjukkan bahwa kemampuan industri broiler dalam berdaya saing ditentukan oleh empat faktor utama, yaitu kemampuan untuk menghasilkan produk dengan biaya produksi yang rendah, integrasi usaha secara vertikal, penerapan teknologi maju, dan iklim usaha yang kondusif. Pada saat ini paling tidak terdapat tiga pola usaha ternak broiler, yakni pola usaha ternak mandiri, kemitraan usaha internal, dan pola kemitraan usaha eksternal. Pada pola usaha ternak mandiri, peternak mendapatkan pasokan dari Poultry Shop (PS) maupun pemasok lain. Pada pola kemitraan usaha internal, pasokan sapronak berupa bibit day old chick (DOC), pakan, serta obatobatan dan vaksin dipenuhi dari pasokan perusahaan pabrik pakan (inti). Pada pola kemitraan usaha eksternal, peternak mitra atau peternak plasma mendapatkan pasokan sapronak (sarana produksi peternakan) dari perusahaan pemodal (inti) yang menjadi mitranya. Pada pola ini peternak tidak memerlukan modal sendiri karena seluruh kebutuhan sapronak dipasok oleh perusahaan inti dengan harga jual output ditentukan melalui kontrak atau mekanisme pasar.

Beberapa permasalahan utama dalam industri broiler (Saptana dan Daryanto, 2013) adalah (a) masalah penyediaan bahan baku pakan industri perunggasan, dimana sebagian besar bahan baku pakan harus diimpor, impor jagung mencapai (40-50 \%); bungkil kedelai (95\%); tepung ikan (90-92\%); serta tepung tulang dan vitamin/feed additive hampir (100 \%) impor; (b) sistem pemasaran yang tidak efisien dan adanya indikasi terjadinya ketimpangan struktur pasar baik pada pasar input maupun pasar output yang menempatkan peternak mandiri dalam posisi lemah; (c) kemitraan usaha broiler belum berjalan secara optimal sehingga koordinasi produk maupun koordinasi antar pelaku belum berjalan secara terpadu; dan (e) industri broiler sangat rentan terhadap gejolak eksternal, seperti krisis ekonomi, wabah penyakit ternak seperti flu burung, dan krisis finansial global dewasa ini.

Situasi pasar komoditas broiler saat ini dihadapkan pada permasalahan-permasalahan berikut: (1) meningkatnya harga sapronak terutama DOC dan pakan ternak; (2) fenomena lonjak harga jagung karena ada pembatasan impor yang menyebabkan melambungnya harga pakan; (3) fluktuasi harga broiler baik di tingkat produsen maupun di tingkat pedagang eceran; dan (4) ketidakmampuan pelaku usaha industri broiler nasional menembus pasar ekspor, seperti ke Jepang dan Timur Tengah.

Pasokan daging ayam domestik sudah mencapai swasembada dimana kebutuhan domestik sepenuhnya dapat dipenuhi produksi dalam negeri. Bahkan pada tahun 2014, jumlah produksi daging ayam mencapai 2,5 juta ton, sementara kebutuhan diperkirakan sebesar 2,3 juta ton (ICN, 2014). Berlebihnya pasokan menyebabkan harga ayam hidup di tingkat peternak turun bahkan hingga dibawah biaya pokok. Namun penurunan harga di tingkat peternak tidak tertransmisikan secara sempurna ke harga daging ayam di pedagang eceran. Harga di tingkat konsumen justru cenderung naik dari waktu ke waktu. Adanya senjang informasi antar pelaku usaha broiler perlu dilakukan pendekatan research gap sehingga dapat dicari akar penyebab senjang yang terjadi baik antar peternak pada berbagai pola maupun antar pelaku usaha di hulu dan di hilir.

Jika permasalahan-permasalahan tersebut terus berlangsung lama maka dikhawatirkan akan menciptakan ketidakpastian dalam usaha industri broiler, menurunnya kapasitas produksi broiler, tidak efisiennya sistem pemasaran broiler, dan semakin tergesernya eksistensi peternak mandiri. Fakta tersebut menunjukkan perlunya dilakukan analisis terhadap aspek produksi dan pemasaran komoditas broiler secara holistik dan komprehensif apa yang menjadi akar permasalahan dan prospek pengembangan industri broiler yang berdaya saing dan berkelanjutan.

Penelitian tentang hubungan antara konsentrasi industri terhadap profitabilitas, efisiensi, produktivitas, dan kekuatan pasar telah dilakukan oleh Azzam (1997), Gopinath et al. (2002), Kim et al. (2002), Resende (2007) dan Mendoza (2013) yang dilakukan secara 
terpisah di berbagai negara dan berbagai sektor, namun kajian pada industri broiler masih relatif terbatas. Hasil kajian Tangendjaja (2010) menunjukkan bahwa Malaysia mempunyai biaya produksi ayam hidup yang lebih rendah dibanding Indonesia, baik ditinjau dari biaya DOC ( 0,21 vs 0,38 US\$) maupun biaya pakan baik stater (0,21 vs 0,24 US\$) maupun grower $(0,20$ vs 0,23 US\$). Produk unggas berkontribusi terhadap konsumsi protein hewani sebesar 60,73\% (Bahri et al. 2008). Menurut Fitriani et al. (2014), sistem integrasi tidak mencapai efisisiensi tinggi disebabkan oleh beberapa faktor: (a) terjadi integrasi semu pada indusri perunggasan, dimana perusahaan peternakan sebagai integrator membentuk semacam anak-anak perusahaan atau cabang usaha-cabang dengan manajemen terpisahpisah; (b) bahan baku pakan ternak tergantung impor yang harganya terus menerus mengalami peningkatan, karena persaingan (food, feed, bio-fuel dan fiber); (c) struktur pasar yang cenderung oligopolistik pada pasar input dan oligopsonistik pada pasar output; dan (d) terjadi fenomena excess profit bagi pelaku usaha tertentu dan marginal profit bagi peternak mandiri.

Secara umum penelitian ini ditujukan untuk menganalisis situasi pasar komoditas broiler di Jawa Barat. Secara rinci tujuan penelitian adalah menganalisis kinerja produksi usaha ternak broiler; menganalisis saluran pemasaran komoditas broiler; menganalisis struktur pasar komoditas broiler; menganalisis integrasi pasar komoditas broiler; dan menganalisis margin tata niaga komoditas broiler.

\section{METODE PENELITIAN}

Kegiatan penelitian dilakukan pada bulan Maret sampai dengan Juli 2016. Penelitian dilakukan di dua Kabupaten dan dua Kota, yaitu Kabupaten Bandung dan Bogor serta dua Kota, yaitu Kota Bandung dan Bogor, Jawa Barat. Penelitian dilakukan dari peternak, perusahaan inti, Rumah Potong Ayam (RPA), dan pedagang pada berbagai tingkatan.

Data sekunder yang digunakan terdiri dari data populasi, produksi dan harga daging ayam yang diperoleh dari berbagai sumber instansi meliputi Ditjen Peternakan dan Kesehatan Hewan, BPS, FAO, Dinas Peternakan Provinsi Jawa Barat, dan Asosiasi Peternak. Data primer diperoleh melalui survei terbatas yang dilaksanakan untuk mendapatkan data dan informasi terkait aspek produksi dan pemasaran. Diskusi terbatas dengan beberapa informan kunci akan dilakukan dengan Ditjen PKH dan Dinas Peternakan, Assosiasi Peternak, dan pelaku usaha agribisnis broiler dalam jumlah terbatas di Kabupaten Bandung, Kota Bandung, Kabupaten Bogor, Kota Bogor dan DKI Jakarta.

Pendekatan penyelesaian masalah dengan menggunakan Struktur-Perilaku-Kinerja (StructureConduct-Performance/S-C-P), seperti yang digunakan Sayaka (2006) dengan pendekatan SCP pada industri benih jagung di Provinsi Jawa Timur mendapatkan hasil struktur pasar produsen benih jagung di Provinsi Jawa Timur berbentuk oligopolistik. Dengan pendekatan yang sama (SCP), Septiani (2013) menganalisis struktur-perilaku-kinerja dalam persaingan industri pakan ternak di Indonesia dan menyimpulkan bahwa struktur pasar industri pakan ternak di Indonesia adalah struktur pasar oligopoli longgar. Perilaku industri pakan ternak di Indonesia menggunakan strategi harga, produk dan promosi. Selanjutnya kinerja industri pakan ternak diperoleh kesimpulan bahwa kinerja industri pakan ternak di Indonesia masih kurang baik.

Desain penelitian dengan menggunakan analisis produksi dan pemasaran. Analisis produksi mencakup struktur biaya produksi dan penerimaan usaha ternak broiler pada pola mandiri, kemitraan internal dan kemitraan eksternal. Analisis pemasaran dengan pendekatan SCP. Metode pengambilan data dilakukan melalui survei dengan menggunakan kuesioner terstruktur melalui wawancara dengan pelaku usaha peternakan.

Metode penarikan contoh dilakukan secara purposive pada berbagai pola usaha ternak broiler. Pengambilan contoh untuk pelaku tata niaga dengan menggunakan metode snowballing dengan menelusuri aliran rantai pemasaran dari hulu hingga hilir. Secara rinci cakupan, jenis, dan jumlah responden ditampilkan pada Tabel 1.

Metode analisis yang digunakan dalam kajian ini adalah terdiri dari dua alat analisis, yaitu analisis struktur biaya produksi dan penerimaaan usaha ternak dan pemasaran. Analisis biaya produksi dan pendapatan dilengkapi dengan analisis biaya pokok dan $\mathrm{R} / \mathrm{C}$ ratio. Sementara itu, analisis pemasaran akan difokuskan pada analisis struktur pasar, margin tata niaga dan analisis integrasi pasar. 
Tabel 1. Sebaran, cakupan, dan jumlah responden di Provinsi, Jawa Barat, 2016

\begin{tabular}{lccccc}
\hline \multicolumn{1}{c}{ Jenis responden } & Kabupaten Bandung & Kota Bandung & Kabupaten Bogor & Kota Bogor & Total \\
\hline Peternak terintegrasi & 2 & - & 2 & - & 4 \\
Peternak plasma & 5 & - & 5 & - & 10 \\
Peternak mandiri & 3 & - & 3 & - & 6 \\
Pedagang pengumpul & 2 & - & 2 & - & 4 \\
Pedagang besar antar wilayah & 2 & 2 & 2 & 2 & 8 \\
Pedagang grosir pasar & 2 & 2 & 2 & 2 & 8 \\
Pedagang pengecer pasar & 2 & 2 & 2 & 2 & 8 \\
Ritel pasar modern & 2 & 2 & 2 & 2 & 8 \\
RPA/RPU & 2 & 2 & 2 & 2 & 8 \\
\hline \multicolumn{1}{c}{ Total } & 22 & 10 & 22 & 10 & 64 \\
\hline \multicolumn{1}{c}{} & & & & &
\end{tabular}

Analisis struktur biaya produksi dan penerimaan Usaha ternak digunakan untuk melihat perbedaan struktur biaya, penerimaan, dan pendapatan dari berbagai pola Usaha ternak dalam menghasilkan komoditas broiler. Untuk melihat tingkat pendapatan digunakan perhitungan sebagaimana dikembangkan oleh Soekartawi (1993), yaitu $\pi=\mathrm{TR}-\mathrm{TC}$, dimana $\pi$ adalah keuntungan (margin) usaha ternak, TR merupakan total penerimaan, dan TC merupakan total biaya.

Return/Cost $(\mathrm{R} / \mathrm{C})$ ratioadalahmerupakan perbandingan antara total penerimaan dengan total biaya. Kriteria keputusan adalah jika $\mathrm{R} / \mathrm{C}>1$, usaha ternak layak diusahakan, jika $\mathrm{R} / \mathrm{C}<1$, usaha ternak rugi, dan jika $\mathrm{R} /$ $\mathrm{C}=1$, usaha ternak berada pada kondisi titik impas.

Secara teoritis struktur pasar dapat dibedakan menjadi dua, yaitu persaingan sempurna dan persaingan tidak sempurna. Persaingan tidak sempurna dibedakan menjadi tiga, yaitu persaingan monopoli, oligopoli dan monopolistik. Struktur pasar dapat dilihat dari tiga hal, yaitu jumlah perusahaan, tipe produksi dan hambatan masuk pasar (Hamond and Dahl, 1977). Dalam kerangka sistematika struktur pasar, kartel masuk dalam struktur pasar oligopoli yang kolusif (Koutsoyannis, 1979). Dikemukakan bahwa ciri-ciri pasar oligopoli adalah (Purcell, 1979; Sukirno, 1985): (1) jumlah perusahaan sangat sedikit; (2) barang yang dihasilkan, saling bersaing di pasar; (3) kemampuannya memengaruhi harga ada; (4) ada barrier to entry; dan (5) pada umumnya perusahaan oligopoli perlu melakukan promosi melalui iklan.

Perilaku pasar merupakan tindakan yang dilakukan perusahaan untuk mencapai tujuan tertentu. Terdapat tiga kriteria untuk melihat perilaku industri, yaitu strategi harga, kondisi entry dan tipe produk. Perilaku pasar mencakup (Asmarantaka, 2009; Saptana dan Saliem, 2015): (a) Penentuan harga dan tingkat output, secara bersama-sama atau price leadership; (b) Perilaku dalam kerja sama antar pelaku usaha dapat direfleksikan oleh pola interaksi dan koordinasi antar pelaku yang dapat diukur juga dengan menggunakan tingkat integrasi pasar; (c) Kebijakan promosi produk, melalui pameran atau iklan; dan (d) predatory and exclusivenary, strategi ini bersifat ilegal. Salah satu model yang dapat digunakan untuk melihat tingkat efisiensi harga adalah Model Ravallion (1986) sebagai berikut:

$$
P_{i t}=\sum_{s=1}^{n} a_{i s} P_{i t-s}+\sum_{s=0}^{n} b_{i s} P_{1 t-s}+X_{i t} c_{i}+e_{i t}
$$

Dimana Pit adalah harga di eceran i di waktu t, Plt adalah harga di produsen, dan Xit adalah faktorfaktor yang memengaruhi harga di eceran. Untuk menangkap besarnya pengaruh kedua variabel tersebut terhadap harga di tingkat petani, Timmer (1987) mengembangkan suatu indeks hubungan pasar yang dikenal dengan nama IMC (Index of Market Conection). IMC merupakan rasio dari koefisien dua variabel harga yang memengaruhi harga yang terjadi di tingkat petani, yaitu $(1+b 1) /(b 3-b 1)$ atau $\beta 1 / \beta 3$. Apabila nilai indeks $\mathrm{IMC}=0$, yaitu $\mathrm{b} 1=-1$, dikatakan pasar terintegrasi dan apabila indeks $\mathrm{IMC}=\sim$, yaitu jika $\mathrm{b} 1=\mathrm{b} 3$, dikatakan pasar tidak terintegrasi.

Dalam memainkan perannya pelaku tata niaga tersebut memperoleh imbalan sebesar perbedaan harga yang diterima produsen dengan harga yang dibayar konsumen. Perbedaan harga tersebut dikenal dengan istilah marjin tata niaga yang terdiri atas 
biaya pemasaran yang dikeluarkan pelaku tata niaga dan keuntungan pemasaran yang diterima pelaku tata niaga (Tomeck dan Robinson, 1990). Secara matematis digunakan rumus sebagai berikut:

$$
M=\sum_{i=1}^{m} C i+\sum_{j=1}^{n} \Pi j
$$

Keterangan:

$$
\begin{aligned}
\mathrm{M}= & \text { marjin pemasaran } \\
\mathrm{Ci}= & \text { biaya pemasaran } \mathrm{I}(\mathrm{I}=1,2,3, \ldots, \mathrm{m}) \\
\mathrm{m}= & \text { jumlah jenis pembiayaan } \\
\pi= & \text { keuntungan yang diperoleh lembaga niaga } \mathrm{j} \\
& (\mathrm{j}=1,2,3, \ldots \mathrm{n}) \\
\mathrm{n}= & \text { jumlah lembaga niaga yang ikut ambil } \\
& \text { bagian dalam proses pemasaran tersebut. }
\end{aligned}
$$

Sumber-sumber pertumbuhan broiler dari sisi permintaan ditentukan oleh faktor jumlah penduduk dan pertumbuhannya, tingkat pendapatan, fenomena urbanisasi dan segmentasi pasar, serta preferensi konsumen (Daryanto, 2009; Saptana dan Daryanto, 2013). Selanjutnya, dikemukakan bahwa sisi penawaran ditentukan produksi, produktivitas dan skala usaha (Daryanto, 2009; Saptana dan Daryanto, 2013). Kondisi industri broiler di Indonesia belum mencapai tahapan keunggulan kompetitif. Indonesia termasuk negara yang tergolong net importer, dimana nilai impor masih lebih besar dari pada nilai ekspornya.

Pertumbuhan ekonomi Indonesia diramalkan akan tetap tumbuh positif sebesar 5-6\% per tahun dan tetap meningkat pada masa lima tahun mendatang. Pertumbuhan ini akan memacu peningkatan konsumsi produk broiler yang bersifat elastis terhadap perubahan pendapatan. Bidang bisnis broiler harus melakukan antisipasi terhadap peningkatan konsumsi tersebut, terutama untuk membuka kesempatan berusaha dan kesempatan kerja melalui pengembangan Usaha ternak, sistem pemasaran yang efisien dan kemitraan usaha secara terpadu untuk memenangkan persaingan baik di pasar domestik maupun pasar global. Secara ringkas kerangka pemikiran keterkaitan aspek produksi dan pemasaran komoditas broiler serta prospek pengembangannya dapat dilihat pada Gambar 1.

Beberepa hipotesis dalam penelitian ini adalah (a) diduga bahwa keuntungan usaha ternak pola mandiri lebih tinggi dibandingkan usaha ternak kemitraan internal dan kemitraan eksternal, hal ini didasari peternak mandiri membeli sapronak secara tunai dengan harga lebih murah dan menjual hasil secara bebas dan tidak terikat kontrak; (b) diduga margin keuntungan tidak terdistribusi secara adil di antara pelakau tata niaga, hal ini didasari kekuatan rebut tawar antar pelaku tata niaga berbeda-beda; dan (c) diduga pasar komoditas broiler tidak terintegrasi dengan baik, disebabkan informasi yang tidak sempurna.

\section{HASIL}

\section{Analisis Usaha Ternak Broiler Pada Berbagai Pola Usaha}

Pada bagian ini akan dilakukan analisis kelayakan Usaha ternak untuk pola mandiri, kemitraan usaha internal dan kemitraan usaha eksternal. Berdasarkan Tabel 2 memberikan beberapa informasi pokok sebagai berikut: (1) besarnya total biaya produksi Usaha ternak broiler pola mandiri skala 20.000 ekor sebesar Rp500.048.625/siklus, kemitraan usaha internal skala 7.000 ekor sebesar 185.681.044/siklus, dan kemitraan usaha eksternal pada skala 5.000 ekor sebesar 132.447.501/siklus; (2) Komponen biaya terbesar pada pola mandiri adalah biaya pakan yang mencapai Rp341.250.000,-/siklus (68,24\%), pola kemitraan internal mencapai Rp133.427.698/siklus (67,87\%), dan pola kemitraan eksternal mencapai Rp86.062.500/ siklus (64,98\%) dari biaya total produksi; (3) Kemudian menyusul biaya pembelian DOC, pada skala pola mandiri mencapai Rp110.000.000/siklus (22,00\%), pola kemitraan internal mencapai Rp42,000,000/siklus $(22,62 \%)$, dan pola kemitraan eksternal mencapai Rp31.500.000/siklus $(23,78 \%)$ dari total biaya produksi; (4) Biaya-biaya variabel lainnya, seperti untuk vaksin, obat-obatan, biaya pemanas, penyusutan kandang atau pemeliharaan kandang pada pola mandiri sebesar Rp41.798.625/siklus (8,36\%), pola kemitraan internal sebesar Rp14.167.243/siklus (7,63\%), dan pada pola kemitraan eksternal sebesar Rp11.375.000/ siklus $(8,59 \%)$ dari biaya total produksi; dan (5) Biaya untuk membayar tenaga kerja pada pola mandiri sebesar Rp7.000.000/siklus (1,40\%), pola kemitraan internal sebesar Rp3.500.001/siklus (1,88 \%), dan pada pola kemitraan usaha eksternal sebesar Rp3.500.001/ siklus $(2,64 \%)$ dari biaya total produksi. 

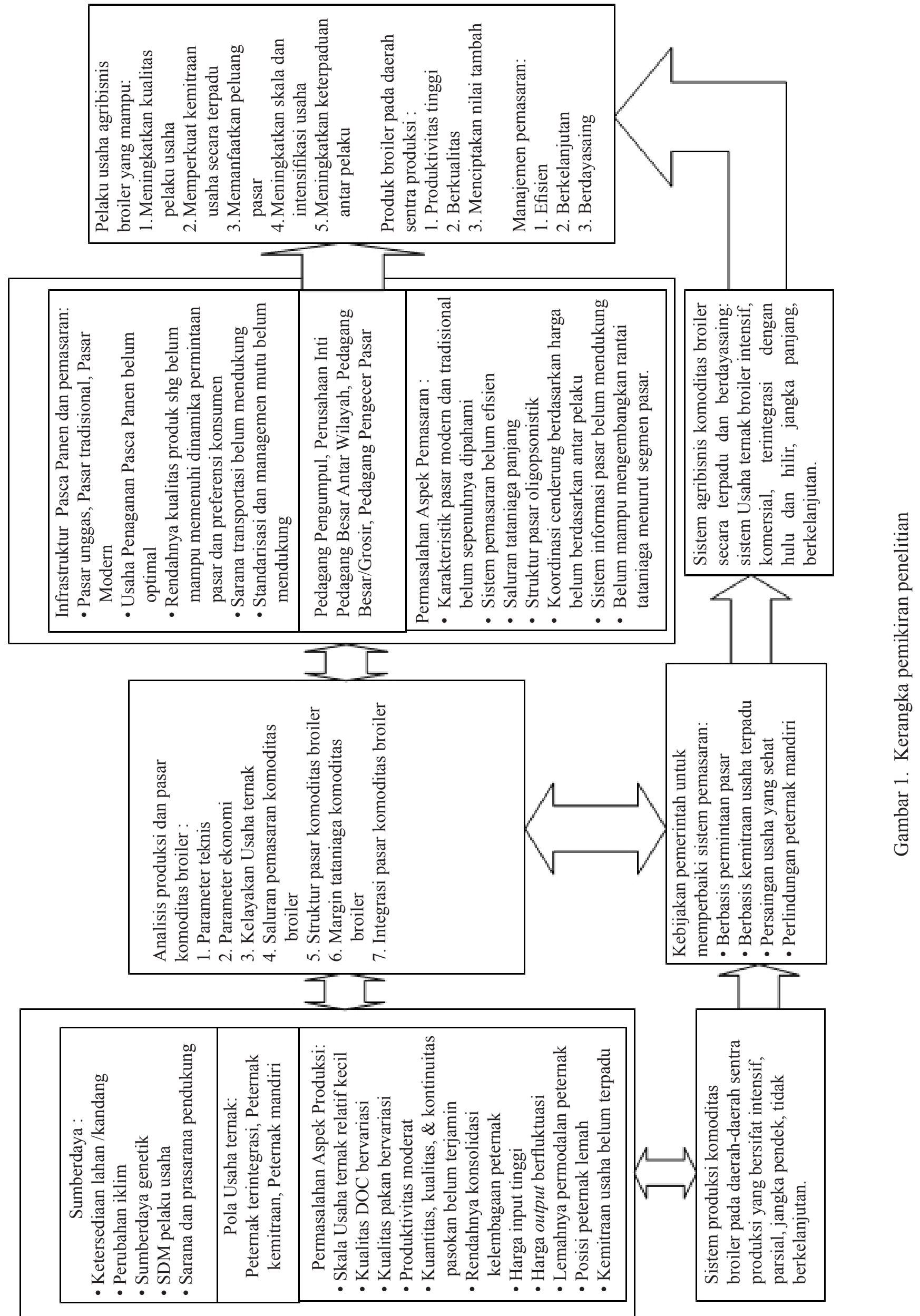
Tabel 2. Analisis usaha ternak broiler pola mandiri, kemitraan internal, dan kemitraan eksternal, Tahun 2016

\begin{tabular}{|c|c|c|c|}
\hline Deskripsi & $\begin{array}{c}\text { Pola mandiri } 20.000 \\
\text { ekor }\end{array}$ & $\begin{array}{c}\text { Kemitraan internal } \\
7.000 \text { ekor }\end{array}$ & $\begin{array}{c}\text { Kemitraan eksternal } \\
5.000 \text { ekor }\end{array}$ \\
\hline Biaya produksi & Nilai (Rp) & Nilai (Rp) & Nilai (Rp) \\
\hline DOC (ekor) & 110.000 .000 & 42.000 .000 & 31.500 .000 \\
\hline Pakan (Kg) & 341.250 .000 & 126.013 .800 & 86.062 .500 \\
\hline Vaksinasi (Rp) & 2.300 .000 & 1.147 .500 & 850.000 \\
\hline Obat-obatan (Rp) & 4.000 .000 & 1.579 .510 & 1.030 .000 \\
\hline Mineral/vitamin (Rp) & 1.700 .000 & 633.333 & 650.000 \\
\hline Jamu (Rp) & 500.000 & 500.000 & 200.000 \\
\hline Molase (Rp) & 1.000 .000 & 350.000 & 250.000 \\
\hline Sekam (karung) & 7.500 .000 & 2.625 .000 & 1.875 .000 \\
\hline Sanitasi (Liter) & 37.500 & 527.400 & 12.500 \\
\hline Tirai (m) & 1.500 .000 & 15.000 & 2.500 .000 \\
\hline Biaya pemanas (Rp) & 9.600 .000 & 3.360 .000 & 1.350 .000 \\
\hline Biaya variabel lain $(\mathrm{Rp})$ & 5.000 .000 & 1.750 .000 & 1.632 .500 \\
\hline Penyusutan (Rp) & 4.843 .750 & 2.000 .000 & 100.000 \\
\hline transportasi (Rp) & 469.375 & 250.000 & 25.000 \\
\hline PBB (Rp) & 78.000 & 35.000 & 900.000 \\
\hline Biaya lainnya (Rp) & 3.270 .000 & 1.144 .500 & 1.166 .667 \\
\hline TK Dalam keluarga (Orang) & 2.333 .333 & 1.166 .667 & 2.333 .334 \\
\hline TK Luar keluarga (Orang) & 4.666 .667 & 2.333 .334 & - \\
\hline Total biaya (Rp) & 500.048 .625 & 185.681 .044 & 132.447 .501 \\
\hline \multicolumn{4}{|l|}{ Penerimaan } \\
\hline Broiler hidup (Kg) & 632.897 .600 & 220.310 .800 & 155.913 .000 \\
\hline Ayam Afkir (Kg) & 7.848 .000 & 750.000 & 350.000 \\
\hline Pupuk kotoran (Kg) & 2.571 .400 & 900.000 & 642.000 \\
\hline Penerimaan (Rp) & 643.317 .000 & 221.960 .800 & 156.905 .000 \\
\hline Pendapatan (Rp) & 143.268 .375 & 36.279 .756 & 24.657 .499 \\
\hline $\mathrm{R} / \mathrm{C}$ & 1.29 & 1.19 & 1.19 \\
\hline Biaya pokok produksi (Rp/Kg) & 17.224 & 18.373 & 18.519 \\
\hline Harga jual $(\mathrm{Rp} / \mathrm{Kg})$ & 21.800 & 21.800 & 21.800 \\
\hline Keuntungan $(\mathrm{Rp} / \mathrm{Kg})$ & 4.576 & 3.427 & 3.281 \\
\hline
\end{tabular}

Gambaran total penerimaan, pendapatan, biaya pokok dan $\mathrm{R} / \mathrm{C}$ ratio pada berbagai pola Usaha ternak adalah sebagai berikut: (1) Besarnya penerimaan total pada pola mandiri sebesar Rp643.317.000 per siklus produksi, pendapatan sebesar Rp143.268.375 per siklus, biaya pokok produksi sebesar Rp17.224 per kg bobot hidup, keuntungan $\mathrm{Rp} 4.576$ per $\mathrm{Kg}$ dan nilai $\mathrm{R} / \mathrm{C}$ ratio sebesar 1,29; (2) Besarnya penerimaan total pada pola kemitraan internal sebesar Rp221.960.800 per siklus, pendapatan sebesar Rp36.279.756 per siklus, biaya pokok produksi sebesar Rp18.373 per kg bobot hidup, keuntungan Rp3.427 per kg, dan nilai $\mathrm{R} / \mathrm{C}$ ratio sebesar 1,19; dan (3) Besarnya penerimaan total sebesar Rp156.905.000 per siklus, tingkat pendapatan sebesar Rp24.657.499 per siklus, biaya pokok produksi sebesar Rp18.519 per kg bobot hidup, kuntungan Rp3.281 per $\mathrm{Kg}$, dan nilai $\mathrm{R} / \mathrm{C}$ ratio sebesar 1,19 .

\section{Pemasaran Komoditas Broiler: Struktur, Perilaku dan Kinerja}

Struktur Pasar

Sumber broiler hidup dari peternak mandiri, peternak kemitraan internal, dan peternak kemitraan eksternal. Sumber perolehan broiler hidup terbesar berasal dari perusahaan inti, karena 90-95\% peternak di Jawa Barat adalah peternak kemitraan dan hanya $5-10 \%$ merupakan peternak mandiri. Penjualan ayam oleh perusahaan inti dilakukan dengan sistem penjualan DO dengan harga telah ditentukan melalui kesepakatan bersama melalui kelembagaan Perhimpunan Insan Perunggasan Rakyat (Pinsar) dengan harga posko. Selanjutnya, pedagang mengambil broiler hidup ke kandang peternak yang telah ditunjuk oleh oleh perusahaan inti. Pedagang 
pengepul selanjutnya menjual ayam hidup dan atau karkas ke beberapa pedagang, yaitu pedagang grosir, pedagang pengecer. Selanjutnya, pedagang grosir menjual ayam kepada pedagang pengecer, meat shop, dan HORECA.

Pertumbuhan yang pesat dalam industri broiler sejauh ini lebih banyak dinikmati oleh perusahaan multinasional yang digerakkan adanya keuntungan skala usaha dan globalisasi sistem rantai nilai dari hulu hingga hilir (Daryanto, 2009). Untuk industri broiler struktur produksi pada kondisi tahun 1990-2000-an menunjukkan pangsa produksi dikuasai oleh perusahaan peternakan skala besar (60\%), skala menengah (20\%) dan skala kecil tinggal (20\%) (Yusdja et al. 1999). Kurang lebih (75\%) pangsa pasar hanya dikuasai oleh 40\% perusahaan (Yudja et al. 2004; Fitriani, 2006; Fitriani et al. 2014). Secara empiris di lapang merefleksikan beberapa hal pokok sebagai berikut: (1) penguasaan oleh perusahaan besar melalui budidaya sendiri, kemitraan usaha internal, dan terakhir melalui pengembangan kandang ayam tertutup (close hause) skala besar-besaran; (2) penguasaan pemodal besar yang berperan sebagai inti dalam kemitraan eksternal juga cukup besar; dan (3) pangsa penguasaan peternak mandiri semakin terbatas.

Beberapa studi mengenai industri perunggasan menegaskan bahwa struktur industri perunggasan sekarang ini mengarah ke oligopolistik (Saptana et al. 2002; Kariyasa dan Sinaga, 2003; Yusdja et al. 2004; Fitriani, 2006). Dari berbagai kajian yang ada dan hasil kajian dilapang menunjukkan adanya indikasi terjadinya integrasi vertikal dalam industri broiler, baik integrasi secara penuh maupun secara semu. Pertanyaannya adalah apakah argumen dasar perusahaan peternakan melakukan integrasi vertikal, di antaranya adalah (Saragih, 1998): (1) bisnis broiler tergolong jenis bisnis berintensitas tinggi yang tingkat keberhasilannya bersandar pada ketepatan pengelolaan pada fase-fase pertumbuhan broiler; (2) produktivitas broiler sangat tergantung pada pakan baik jumlah maupun mutunya, hal ini mengisyaratkan pentingnya sinkronisasi pengelolaan penyediaan pakan dengan fase-fase pertumbuhan broiler; dan (3) produk akhir dari industri broiler merupakan produk yang dihasilkan melalui tahapan-tahapan produksi mulai dari hulu hingga ke hilir, di mana produk antara adalah makluk biologis bernilai ekonomi tinggi.
Dengan karakteristik dasar yang demikian menuntut pengelolaan bisnis broiler dilakukan terintegrasi secara vertikal. Dalam hal ini peternak mandiri akan menghadapi masalah ganda, yaitu masalah pada pasar input dan sekaligus masalah pada pasar output. Peternak akan sebagai price taker pada pasar input dan terpaksa harus membayar harga input lebih mahal. Pada sisi output, peternak peternak mandiri menghadapi struktur pasar yang oligopsonistik. Karena produksi broiler hidup dikuasai perusahaan peternakan skala besar melalui kemitraan internal (63\%), sebagian lain dikuasai oleh pemodal melalui kemitraan eksternal (27\%), dan peternak mandiri hanya menguasai pangsa pasar relatif kecil (10\%).

Untuk komoditas broiler peternak mandiri menghadapi struktur pasar yang oligopsonistik, karena harga ditentukan oleh perusahaan inti baik kemitraan internal maupun kemitraan eksternal. Harga ditentukan melalui harga patokan oleh pinsar dengan apa yang dinamakan harga posko. Harga jual peternak mandiri, kemitraan internal dan kemitraan eksternal mengikuti harga patokan dari pinsar atau harga Posko. Perusahaan peternakan skala besar yang menjadi inti bersifat oligopolistik terhadap pedagang pengepul (broker). Sementara itu, pedagang grosir dan pedagang pengecer mengacu dengan harga broiler hidup yang telah ditentukan melalui harga patokan atau harga posko.

\section{Integrasi Pasar}

Perilaku pasar broiler dapat dianalisis dengan integrasi pasar. Analisis integrasi pasar dilakukan pada dua tingkatan, yaitu (a) tingkat peternak ke pedagang grosir, (b) tingkat pedagang grosir ke pedagang pengecer. Berdasarkan hasil analisis integrasi pasar untuk komoditas daging broiler dari tingkat petani (peternak) ke pedagang besar (grosir) di Provinsi Jawa Barat diperoleh hasil estimasi sebagai berikut:

$\mathrm{P}_{\mathrm{t}}=1265,167 *+1,024 \mathrm{P}_{\mathrm{t}-1}^{* *}+0,046\left(\mathrm{P}_{\mathrm{d}}-\mathrm{P}_{\mathrm{d}-1}\right)-0,068$ $\mathrm{P}_{\mathrm{d}-1} * *$

$\mathrm{R}^{2}=0,957$

IMC $=-15,057$ (tidak terintegrasi)

\section{Keterangan:}

$\mathrm{P}_{\mathrm{t}} \quad=$ harga di tingkat peternak saat ini

$\mathrm{P}_{\mathrm{t}-1}=$ harga di tingkat peternak periode sebelumnya

$\mathrm{P}_{\mathrm{d}} \quad=$ harga di tingkat pedagang besar 
$\mathrm{P}_{\mathrm{d}-1}=$ harga di tingkat pedagang besar periode sebelumnya

*) = signifikan $10 \%$

**) $=$ signifikan $5 \%$

$* * *)=$ signifikan $1 \%$

Koefisien $b_{2}$ pada hasil estimasi menunjukkan seberapa jauh harga ditingkat pedagang grosir daging broiler di Kota Bandung ditransmisikan ke tingkat peternak. Nilai b2 yang diperoleh dari hasil estimasi diatas diperoleh nilai sebesar 0,046 atau jauh lebih kecil dari angka 1 (satu). Hasil estimasi ini berarti bahwa dalam jangka pendek perubahan harga broiler di tingkat pedagang grosir di Kota Bandung tidak ditransmisikan secara sempurna ke tingkat peternak. Dimana kenaikan harga daging broiler (1\%) ditingkat pedagang grosir hanya menyebabkan kenaikan harga $(0,046 \%)$ ditingkat peternak broiler. Hasil analisis ini sejalan dengan hipotesis, yaitu integrasi pasar komoditas broiler antara pedagang grosir dengan peternak tidak terintegrasi dengan baik.

Pengaruh harga pada tingkat peternak periode sebelumnya terhadap harga tingkat peternak saat ini bertanda positif dan diatas satu, yaitu sebesar 1,024. Berbeda halnya dengan pengaruh harga pedagang grosir daging broiler periode sebelumnya yang bertanda negatip dan kontribusinya kurang dari satu, yaitu sebesar -0,068. Hasil estimasi ini menunjukkan bahwa pengaruh harga ditingkat pedagang grosir di Kota Bandung periode sebelumnya lebih kecil dibandingkan dengan harga ditingkat peternak broiler periode sebelumnya terhadap tingkat harga ditingkat peternak saat ini.

Hasil perhitungan diperoleh nilai IMC sebesar 15,057. Hal ini berarti bahwa keterpaduan pasar broiler di Kota Bandung antara harga broiler di tingkat peternak dan harga grosir tidak terintegrasi dengan baik. Tidak terjadinya keterpaduan pasar broiler tersebut disebabkan harga broiler di Jawa Barat saat ini cenderung mengikuti harga Posko yang ditentukan Pinsar. Dimana para pedagang membeli broiler ke peternak dengan berpatokan pada harga Posko sebagai harga acuan. Sementara itu, penentuan harga posko lebih ditentukan oleh biaya pokok produksi daging broiler, dimana besaran biaya pokok produksi broiler sangat ditentukan harga pakan ternak. Berdasarkan hasil analisis integrasi pasar untuk komoditas broiler dari tingkat pedagang grosir ke pedagang pengecer di
Provinsi Jawa Barat diperoleh hasil estimasi sebagai berikut:

$$
\begin{aligned}
& \mathrm{P}_{\mathrm{d}}=-32.506+1,274 \mathrm{P}_{\mathrm{d}-1} * * *+0,932\left(\mathrm{P}_{\mathrm{c}}-\mathrm{P}_{\mathrm{c}-1}\right) * * *+ \\
& \quad \begin{array}{l}
0,322 \mathrm{P}_{\mathrm{c}-1} * * \\
\mathrm{R}^{2}=
\end{array} \\
& \mathrm{IMC}=-3,999 \text { (tidak terintegrasi) }
\end{aligned}
$$

\section{Keterangan:}

$$
\begin{aligned}
\mathrm{P}_{\mathrm{d}}= & \text { harga di tingkat pedagang besar } \\
\mathrm{P}_{\mathrm{d}-1}= & \text { harga di tingkat pedagang besar periode } \\
& \text { sebelumnya } \\
\mathrm{P}_{\mathrm{c}}= & \text { harga di tingkat pengecer } \\
\mathrm{P}_{\mathrm{c}-1}= & \text { harga di tingkat pengecer periode } \\
& \text { sebelumnya } \\
*)= & \text { signifikan } 10 \% \\
* *)= & \text { signifikan } 5 \% \\
* * *)= & \text { signifikan } 1 \%
\end{aligned}
$$

Nilai $b_{2}$ yang diperoleh pada estimasi diatas menunjukkan sebesar 0,932 atau mendekati angka 1 . Hasil estimasi ini berarti bahwa dalam jangka pendek perubahan harga broiler di tingkat pedagang pengecer di Kota Bandung ditransmisikan dengan dengan cukup baik ke tingkat pedagang besar daging broiler. Dimana kenaikan harga daging broiler 1\% ditingkat pedagang pengecer menyebabkan kenaikan harga $0,932 \%$ ditingkat pedagang grosir. Hasil analisis ini memberikan hasil yang berbeda dengan hipotesis yang telah dirumuskan, yaitu integrasi pasar komoditas broiler antara pedagang pengecer dengan pedagang grosir terintegrasi dengan cukup baik.

Pengaruh harga pada tingkat pedagang besar periode sebelumnya terhadap harga tingkat pedagang besar saat ini bertanda positif lebih besar dari satu, yaitu sebesar 1,274. Dengan besaran yang lebih kecil dari satu namun dengan tanda yang juga positif juga diperoleh pada pengaruh harga pedagang pengecer broiler sebelumnya yang kontribusinya kurang dari satu, yaitu sebesar 0,322. Hasil estimasi ini menunjukkan bahwa pengaruh harga ditingkat pedagang pengecer di Kota Bandung periode sebelumnya lebih kecil dibandingkan dengan harga ditingkat pedagang besar daging broiler periode sebelumnya terhadap tingkat pedagang grosir daging broiler saat ini.

Hasil perhitungan diperoleh nilai IMC sebesar -3,953. Hal ini menunjukkan tingkat keterpaduan pasar broiler di Kota Bandung antara harga broiler di tingkat pedagang grosir dan harga pengecer adalah tidak 
terintegrasi dengan baik. Kurang adanya keterpaduan pasar tersebut, karena harga broiler pedagang besar saat ini cenderung mengikuti harga posko yang ditentukan Pinsar yang merupakan wadah perusahaan-perusahaan besar peternakan dalam melakukan kesepakatan harga posko bersama. Sementara itu, harga Posko sangat ditentukan biaya pokok produksi usaha ternak dan biaya pokok produksi sangat ditentukan harga pakan ternak. Di samping itu, harga broiler di Kota Bandung juga banyak dipengaruhi oleh pasokan dari daerah sentra produksi (Tasikmalaya, Ciamis, Bandung, Bogor) dan harga di tujuan pasar utama DKI Jakarta.

\section{Margin Tata niaga Broiler}

Marjin tata niaga atau marjin pemasaran produk broiler di Jawa Barat dibedakan menurut tiga saluran pemasaran berdasarkan pola usaha ternak, yaitu saluran pemasaran pola usaha ternak mandiri, kemitraan usaha internal, dan kemitraan usaha ternak eksternal. Margin pemasaran dilakukan pada saluran pemasaran dominan. Pada Tabel 3 menyajikan secara rinci biaya yang dikeluarkan oleh masing-masing pelaku tata niaga serta marjin tata niaga yang diterima pelaku tata niaga broiler pada berbagai pola usaha ternak.

Berdasarkan struktur biaya, serta harga beli dan harga jual diperoleh beberapa informasi pokok: (a) pangsa harga yang diterima peternak setara daging ayam adalah $85,49 \%$, yang menunjukkan cukup tingginya pangsa harga yang diterima peternak; (b) besarnya total margin tata niaga setara daging ayam sebesar Rp4.475 per Kg daging ayam, yang terdiri atas biaya margin tata niaga Rp2.625 per Kg daging ayam dan keuntungan yang diterima pelaku tata niaga sebesar Rp1.850 per $\mathrm{Kg}$ daging ayam; (c) secara berturut-turut keuntungan terbesar diterima oleh pedagang pengecer sebesar Rp975 per Kg, pedagang pengepul/agen/broker sebesar Rp800 per $\mathrm{Kg}$, dan pedagang besar/grosir di pasar sebesar Rp850 per Kg; dan (d) Meskipun demikian, jika dilihat keuntungan total maka keuntungan terbesar diterima oleh pedagang pengepul/agen/broker dan pedagang besar/grosir dengan volume penjualan yang jauh lebih besar dibandingkan pedagang pengumpul dan pengecer.

Struktur biaya dan keuntungan tata niaga antara tiga pola usaha ternak broiler di Jawa Barat hampir sama. Hal ini antara lain disebabkan oleh: (a) struktur produksi broiler dikuasai oleh perusahaan peternakan skala besar dengan pangsa (85-90 \%); (b) adanya harga
Posko yang ditentukan Pinsar sebagai acuan pedagang pengepul atau pedagang besar dalam menebus broiler hidup di peternak yang menjadi anggota mitra usahanya; (c) tujuan pasar yang relatif sama antara ketiga pola usaha ternak tersebut, yaitu untuk pasar tradisional atau pasar becek. Hasil analisis margin tata niaga ini juga menunjukkan adanya struktur pasar yang cenderung oligopolistik dan mengarah kartel pada pasar daging broiler di Jawa Barat, yaitu dengan adanya penentuan Posko dari Pinsar yang menjadi harga acuan oleh pedagang ayam yang mau menebus broiler ke peternak anggota mitra baik internal maupun eksternal.

\section{Implikasi Manajerial}

Hasil penelitian ini juga memberikan implikasi manajerial bagi peternak mandiri yang telah dilakukan pembinaan perlu tergabung dalam koperasi agribisnis perunggasan terintegrasi, dengan didukung pengembangan breeding, feedmill, RPA, dan meat shop . Bagi peternak yang tidak mampu, diarahkan menjadi plasma dalam sistim kemitraan internal dan eksternal, dengan skala usaha minimal 5000 ekor dan dengan tingkat pendapatan Rp10 juta per siklus produksi. Selanjutnya, bagi Komisi Pengawas Persaingan Usaha (KPPU) dan pemerintah secara bersama-sama harus memperbaiki struktur pasar komoditas broiler dan daging ayam. KPPU harus melakukan penegakan hukum terhadap perusahaan peternakan skala besar jika secara meyakinkan terbukti terjadi persaingan usaha tidak sehat dalam industri broiler. Pemerintah perlu membangun infrastruktur yang dapat mendukung pengembangan industri broiler di daerah sentra produksi dan kebijakan perlindungan kepada peternak mandiri melalui kebijakan subsidi input dan penetapan harga referensi. Di sisi lain, Pemerintah perlu membuat kebijakan tentang kemitraan agribisnis perunggasan yang didasari kajian akademik, dilakukan secara adil dan dinamis. Adil baik bagi peternak mitra maupun bagi perusahaan inti melalui pembagian keuntungan dan risiko yang adil dan dinamis. Adil yang didasarkan kontribusinya masing-masing pihak dan dinamis dalam arti bahwa kesepakatan-kesepakatan yang dituangkan dalam kontrak bersifat dinamis mengikuti perubahan biaya produksi dan harga broiler dan daging ayam. Dalam hubungan ini, strategi peningkatan efisiensi tata niaga dapat dilakukan melalui pendekatan manajemen rantai pasok secara terpadu sehingga terbangun keterpaduan produk dan keterpaduan antar pelaku usaha. 
Tabel 3. Analisis margin tata niaga komoditas broiler pada pola usaha ternak mandiri, kemitraan internal, dan kemitraan eksternal, di Jawa Barat, 2016

\begin{tabular}{|c|c|c|c|}
\hline \multirow[t]{2}{*}{ Uraian } & Pola mandiri & Kemitraan internal & Kemitraan eksternal \\
\hline & Biaya/Harga $(\mathrm{Rp} / \mathrm{Kg})$ & Biaya/Harga $(\mathrm{Rp} / \mathrm{Kg})$ & Biaya/Harga $(\mathrm{Rp} / \mathrm{Kg})$ \\
\hline Peternak & 21.800 & 18.000 & 18.000 \\
\hline \multicolumn{4}{|l|}{ Pedagang pengepul/agen/broker } \\
\hline 1. Harga beli ayam hidup $(\mathrm{Rp} / \mathrm{Kg})$ & 21.800 & 18.000 & 18.000 \\
\hline \multicolumn{4}{|l|}{ 2. Biaya yang dikeluarkan } \\
\hline a. Biaya transportasi & 300 & 350 & 375 \\
\hline b. Bongkar-muat & 100 & 100 & 100 \\
\hline c. Biaya handling/packing & 100 & 100 & 100 \\
\hline \multicolumn{4}{|l|}{ d. Biaya } \\
\hline Penampungan/penyimpanan & 150 & 150 & 150 \\
\hline e. Biaya lainnya (retribusi) & 25 & 25 & 25 \\
\hline Subtotal biaya & 675 & 725 & 750 \\
\hline 3. Harga jual & 23.275 & 19.700 & 19.750 \\
\hline 4. Keuntungan & 800 & 975 & 1.000 \\
\hline \multicolumn{4}{|l|}{ Pedagang besar/grosir } \\
\hline 1. Harga beli ayam hidup $(\mathrm{Rp} / \mathrm{Kg})$ & 23.275 & 19.700 & 19.750 \\
\hline \multicolumn{4}{|l|}{ 2. Harga beli konversi daging ayam } \\
\hline$(\mathrm{Rp} / \mathrm{Kg})$ & 31.000 & 28.150 & 28.225 \\
\hline \multicolumn{4}{|l|}{ 2. Biaya yang dikeluarkan } \\
\hline a. Biaya pemotongan & 750 & 750 & 750 \\
\hline b. Biaya transportasi & 150 & 150 & 150 \\
\hline c. Bongkar-muat & 100 & 100 & 100 \\
\hline c. Biaya handling/packing & 50 & 50 & 50 \\
\hline d. Biaya lainnya (retribusi) & 25 & 25 & 25 \\
\hline Subtotal biaya & 975 & 975 & 1.075 \\
\hline 3. Harga jual & 32.825 & 30.000 & 30.175 \\
\hline 4. Keuntungan & 850 & 875 & 875 \\
\hline \multicolumn{4}{|l|}{ Pedagang pengecer } \\
\hline 1. Harga beli & 32.825 & 30.000 & 30,175 \\
\hline \multicolumn{4}{|l|}{ 2. Biaya yang dikeluarkan } \\
\hline a. Biaya transportasi & 100 & 150 & 150 \\
\hline b. Bongkar-muat & 50 & 50 & 50 \\
\hline d. Biaya sewa tempat & 25 & 25 & 25 \\
\hline e. Biaya lainnya (retribusi) & 25 & 25 & 25 \\
\hline Subtotal biaya & 200 & 250 & 250 \\
\hline 3. Harga jual (Kg) & 34.000 & 31.500 & 31.675 \\
\hline 4. Keuntungan & 975 & 1.250 & 1.250 \\
\hline
\end{tabular}

\section{KESIMPULAN DAN SARAN}

\section{Kesimpulan}

Usaha ternak broiler baik pada pola mandiri, kemitraan internal, dan kemitraan eksternal menguntungkan dan layak diusahakan, secara berturut-turut keuntungan terbesar diterima peternak mandiri, peternak kemitraan internal, dan peternak kemitraan eksternal. Namun, peternak mandiri yang mampu bertahan adalah peternak skala menengah dan besar.

Struktur pasar yang dihadapi peternak mandiri adalah struktur pasar yang bersifat oligopsonistik dimana harga lebih ditentukan oleh pedagang pengepul/broker, sedangkan struktur pasar yang dihadapi peternak mitra internal dan eksternal lebih sebagai pekerja perusahaan inti, peternak mendapatkan insentif jika melakukan 
Usaha ternak dengan indikator parameter teknis yang baik. Struktur pasar yang dihadapi pedagang pengepul (broker) dan pedagang grosir di pasar terhadap perusahaan inti adalah struktur pasar oligopoli yang mengarah ke bentuk kartel, karena harga ditentukan sepihak oleh perusahaan inti melalui kelembagaan Pinsar yang disebut harga posko. Struktur pasar yang dihadapi pedagang pengecer di pasar-pasar tradisional di Kota Bandung dan Bogor terhadap pedagang diatasnya cenderung mengarah ke pasar monopolistik.

Keuntungan pelaku tata niaga per unit output dalam pemasaran broiler lebih besar dibandingkan biaya yang dikeluarkan kecuali bagi pedagang grosir dimana biaya per unit output lebih besar daripada keuntungan yang diperolehnya. Keuntungan terbesar diterima pelaku tata niaga secara berturut-turut adalah pedagang pengecer, pedagang pengepul, dan pedagang grosir di pasar. Namun, jika dilihat besaran total keuntungan maka margin keuntungan diterima pedagang pengepul/ broker dan pedagang grosir yang paling besar karena omzet penjualan yang besar. Berdasarkan kinerja margin tata niaga tiap pelaku usaha di Jawa Barat dapat disimpulkan bahwa pemasaran komoditas broiler tidak efisien.

Keterpaduan pasaryang diindikasikan oleh harga broiler di tingkat peternak dan di tingkat pedagang grosir, serta keterpaduan pasar di tingkat pedagang grosir dengan di tingkat pedagang pengecer di Kota Bandung tidak terintegrasi dengan baik. Pembentukan harga broiler hidup di tingkat produsen sangat ditentukan oleh kekuatan oligopoli yang cenderung ke bentuk kartel perusahaan peternakan skala besar melalui penentuan harga posko oleh Pinsar. Pembentukan harga daging ayam di tingkat pasar eceran selain dipengaruhi oleh kekuatan oligopoli perusahaan peternakan skala besar, faktor kekuatan penawaran dan permintaan masih cukup berpengaruh.

\section{Saran}

Saran untuk penelitian lebih lanjut adalah melakukan penelitian SCP dalam cakupan wilayah yang lebih luas sehingga dapat menggambarkan SCP struktur industri broiler suatu wilayah atau agregat nasional. Penelitian lanjutan disarankan dapat mengintegrasikan daerahdaerah sentra produksi dengan pusat-pusat konsumsi yang memiliki keterkaitan pasat yang kuat sehingga integrasi pasar komoditas antara daerah sentra produksi dengan pusat pasar dapat dipetakan dengan baik.

\section{DAFTAR PUSTAKA}

Azzam AM. 1997. Measuring market power and costefficiency effects of industrial concentration. The Journal of Industrial Economics 45(4): 00221821. https://doi.org/10.1111/1467-6451.00054.

Aho P. 1998. How globalization of agriculture will affect the poultry and livestock industries of Southeast Asia. ASA Technical bulletin. PO 39. American Soybean Association, Liat Tower, Singapore.

Asmarantaka RW. 2009. Pemasaran Produk-Produk Pertanian dalam Bunga Rampai Agribisnis Seri Pemasaran. Bogor: Departemen Agribisnis, Fakultas Ekonomi dan Manajemen, Institut Pertanian Bogor.

Daryanto A. 2009. Dinamika Dayasaing Industri Peternakan. Bogor: IPB Press.

Ditjen PKH. 2013. Statistik Peternakan. Direktorat Jenderal Peternakan dan Kesehatan Hewan. Jakarta: Departemen Pertanian.

Dahl, Dale C, Jerome WH. 1977. Market and Price Analysis, The Agricultural Industries. USA: McGraw-Hill.

Fitriani A, Daryanto HK, Nurmalina R, Susilowati SH. 2014. Struktur, perilaku dan kinerja industri broiler indonesia: pendekatan model simultan. Jurnal Agro Ekonomi 32(2): 167-186. https:// doi.org/10.21082/jae.v32n2.2014.167-186.

Gopinath M, Pick D, Li Y. 2002. Does Industrial Concentration Raise Productivity in Food Industries? Presented at 2002 Annual Meeting of the Western Agricultural Economics Association. California.

Koutsoyannis A. 1979. Modern Microeconomics. Second Edition. London; The Macmillan Press LTD. https://doi.org/10.1007/9781349160778.

Kim CS, Hallahan C, Taylor H, Schluter G. 2002. Market Power and Cost-Efficiency Effects of the Market Concentration in the U.S. Nitrogen Fertilizer Industry. presented at the AAEA meetings, Long Beach, CA, July 28-31, 2002.

Kariyasa K, Sinaga BM. 2003. Analisis Perilaku Pasar Pakan dan Daging Ayam Ras di Indonesia: Pendekatan Model Ekonometrika Simultan. Bogor: Pusat Analisis Sosek dan Kebijakan Pertanian.

Mendoza RU, Barcenas LA, Mahurkar P. 2013. Balancing industrial concentration and competition for economic development in Asia: Insight from South Korea, China, India, 
Indonesia, and the Philippines. Journal of Reviews on Global Economics 2: 248-277. https://doi.org/10.6000/1929-7092.2013.02.20.

Purcel, Wayne D. 1979. Agriculture Marketing: System, Coordination, Cash and Future Prices. A Prentice-Hall Company. Virginia: Reston.

Ravallion M. 1986. Testing Market Integration American Agricultural Economics Association.

Sukirno S. 1985. Pengantar Teori Mikro Ekonomi. Jakarta:Fakultas Ekonomi Universitas Indonesia.

Saragih B. 1998. Agribisnis Berbasis Peternakan. Bogor: Pusat Studi Pembangunan, Lembaga, Penelitian Institut Pertanian Bogor.

Soekartawi A, Soeharjo, Dillon JL, Hardaker JB. 1993. Ilmu Usahatani dan Penelitian Untuk Pengembangan Petani Kecil. Jakarta: UI-Press.

Sayaka B. 2006. Market structure of the corn seed industry in East Java. Jurnal Agro Ekonomi 24(2): 133-156. https://doi.org/10.21082/jae. v24n2.2006.133-156.

Resende M. 2007. Structure, conduct and performance: a simultaneous equations investigation for the brazilian manufacturing industry. Applied Economics 39: 937-942. https://doi. org/10.1080/00036840500461949.

Septiani, M dan M F Alexandi. 2014. Struktur perilaku kinerja dalam persaingan industri pakan ternak di Indonesia Periode Tahun 1986-2010. Jurnal Manajemen \& Agribisnis 11(2): 77-88.
Saptana, DaryantoA. 2013. Dinamika Kemitraan Usaha Agribisnis Berdayasaing dan Berkelanjutan. Bogor: Pusat Sosial Ekonomi dan Kebijakan Pertanian. Badan Penelitian dan Pengembangan Pertanian, Kementerian Pertanian.

Timmer CP. 1987. Corn Marketing, In Indonesia, In The Corn Economy of Indonesia, ed. C.P. Timmmer, Ch.8, pp. 201-234. Ithaca, New York: University Press.

Tomeck, William G, Robinson KL. 1990. Aricultural Product Prices. Third Edition. Cornell University Press.

Tangendjaja B. 2010. Global competitiveness of poultry production in South East Asia Countries. Wartazoa 20(4): 161-171.

Tangendjaja, B. 2014. Usaha Meningkatkan Daya Saing Perunggasan Indonesia, Memperkuat Dayasaing Produk Pertanian. Jakarta: Badan Penelitian dan Pengembangan Pertanian, Kementerian Pertanian.

Yusdja Y, Sayuti R, lqbal M, Tambunan. 1999. Perumusan Kebijaksanaan dan Model Restrukturisasi Industri TernakUnggas Nasional. Bogor: Pusat Penelitian Sosial Ekonomi Pertanian. Badan Penelitian dan Pengembangan Pertanian.

Yusdja Y, Ilham N, Sayuti R. 2004. Tinjauan penerapan kebijakan industri ayam ras: antara tujuan dan hasil. Forum Penelitian Agro Ekonomi 22(1): 22-36 